\title{
Relative effects of grazers and nutrients on seagrasses: a meta-analysis approach
}

\author{
A. Randall Hughes ${ }^{1,2, *}$, K. Jun Bando ${ }^{2}$, Laura F. Rodriguez ${ }^{2,3}$, Susan L. Williams ${ }^{1}$ \\ ${ }^{1}$ Bodega Marine Laboratory, University of California-Davis, PO Box 247, Bodega Bay, California 94923-0247, USA \\ ${ }^{2}$ Department of Environmental Science and Policy, University of California-Davis, Davis, California 95616, USA \\ ${ }^{3}$ Instituto de Biología, Ecología, y Conservación, A.C. Santa Ana 37, Las Fuentes, Zapopan, Jalisco 45070, Mexico
}

\begin{abstract}
Recent large-scale seagrass declines have prompted experimental investigations of potential mechanisms. Although many studies have implicated eutrophication or reductions of epiphyte grazers in these declines, few experiments have simultaneously manipulated both factors to assess their relative effects. This study used meta-analyses of 35 published seagrass studies to compare the relative strength of 'top-down' grazer effects and 'bottom-up' nutrient effects on epiphyte biomass and seagrass above-ground growth rate, above-ground biomass, below-ground biomass, and shoot density. A surprising result was that seagrass growth and biomass were limited in situ by sediment nutrients; light limitation has been emphasized in the literature to date. Water column enrichments, which were correlated with increased epiphyte biomass, had strong negative effects on seagrass biomass. Grazers overall had a positive effect on shoot density, but negligible effects on seagrass biomass and growth rate. However, analyzing epiphyte grazers separately from other grazers revealed positive effects of grazing on seagrass response variables and corresponding negative impacts on epiphyte biomass. The positive effects of epiphyte grazers were comparable in magnitude to the negative impacts of water column nutrient enrichment, suggesting that the 2 factors should not be considered in isolation of each other. Until the determinants of epiphyte grazer populations are empirically examined, it will be difficult to address the contribution that overfishing and cascading trophic effects have had on seagrass decline. Because increases in water column nutrients are documented in many regions, efforts to reduce coastal eutrophication are an appropriate and necessary focus for the management and conservation of seagrass ecosystems.
\end{abstract}

KEY WORDS: Seagrasses · Meta-analysis · Epiphyte · Nutrients · Grazers • Management · Eutrophication · Top-down/bottom-up

\section{INTRODUCTION}

Recent theoretical and empirical studies have clearly linked anthropogenic stressors to dramatic and widespread declines in the functioning of coastal marine ecosystems (Dayton et al. 1998, Lenihan \& Peterson 1998, Fourqurean \& Robblee 1999, Hughes et al. 2003, Stankelis et al. 2003). Among the most pervasive anthropogenic disturbances to coastal ecosystems are eutrophication (Howarth et al. 2000) and overfishing (Jackson et al. 2001). Anthropogenic changes have a particularly strong impact on ecosys- tem function when they affect ecologically important species such as seagrasses (Orth \& Moore 1983, Short \& Wyllie-Echeverria 1996, Hall et al. 1999). The prevalence of fishing pressures and nutrient loading in coastal systems and the strong experimental tradition in seagrass community ecology make seagrass beds ideal systems in which to explore the basic ecological importance of 'top-down' (i.e. higher trophic level influences, including predation) and 'bottom-up' (i.e. resource supply to primary producers) processes (Williams \& Heck 2001; see Fig. 1 for a depiction of the seagrass food web). 


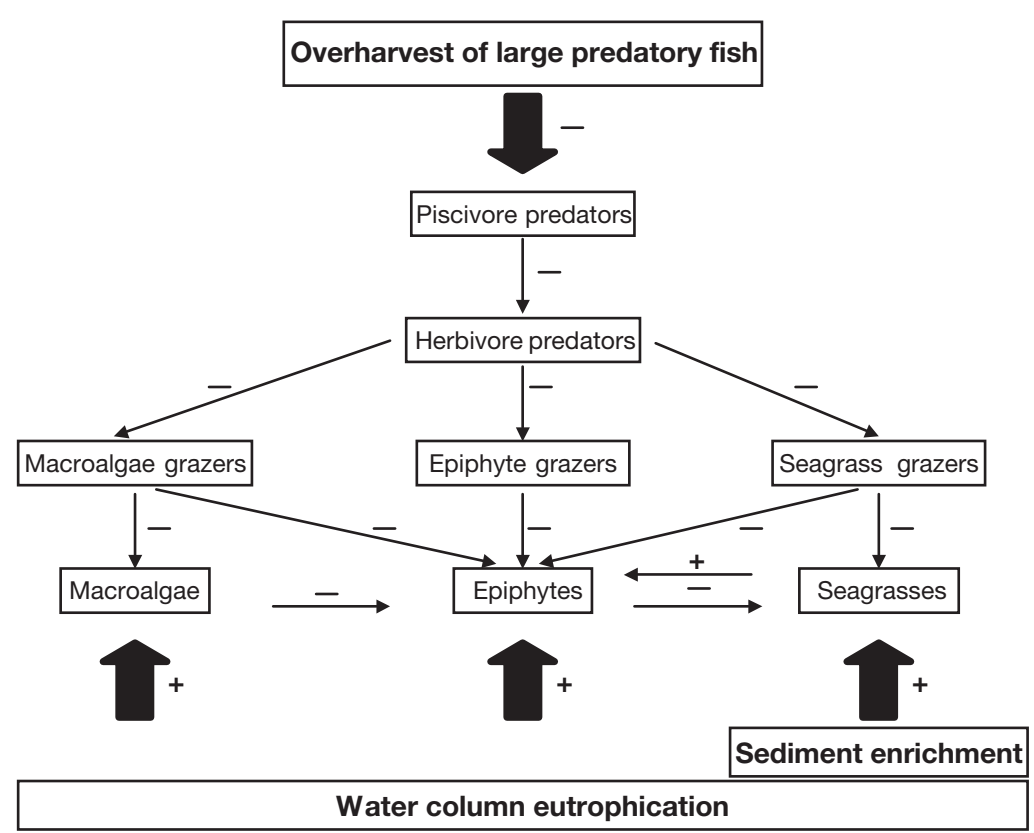

Fig. 1. Food web diagram depicting key seagrass species groups, their interactions, and key anthropogenic disturbances (overharvesting large predators, eutrophication). +/- signs by arrows indicate direction of effect. The negative effect of macroalgae on epiphytes is hypothesized

In recent years, seagrass ecosystems have experienced significant global declines in areal extent and habitat value (Orth \& Moore 1983, Short \& WyllieEcheverria 1996, Hall et al. 1999). Eutrophication is generally regarded as a major driver of widespread contemporary declines of seagrasses and other submerged aquatic vegetation because it stimulates overgrowth of epiphytic algae and macroalgae from the 'bottom-up' (Walker \& McComb 1992, Duarte 1995, Valiela et al. 1997). By virtue of their physical position in the water column and their superior nutrient uptake kinetics, algal epiphytes can intercept light and water column nutrients and reduce the diffusion of carbon and oxygen across seagrass leaves (Sand-Jensen 1977, Sand-Jensen et al. 1985), leading to seagrass decline. Similarly to epiphytes, macroalgal blooms shade seagrasses, leading to declines (Hauxwell et al. 2003).

Trophic interactions are also gaining recognition as critical structuring forces in seagrass systems (Cebrián \& Duarte 1998, Hauxwell et al. 1998, Heck et al. 2000, Williams \& Heck 2001). Large herbivores including sea urchins, fishes, geese, manatees, dugongs and green turtles can significantly reduce seagrass biomass (Thayer et al. 1982, Valentine \& Heck 1991). Small invertebrate grazers of epiphytes (i.e. amphipods, isopods, gastropods and herbivorous crabs) and their predators can also play important structuring roles that include mediating the effects of water column eutrophication on seagrasses (Howard
1982, Hootsmans \& Vermaat 1985, Neckles et al. 1993, Williams \& Ruckelshaus 1993). Clear documentation that large predatory fishes are over-harvested in coastal waters has led to the hypothesis that over-exploitation of top predators contributes to seagrass decline through the same proximate mechanism as eutrophication: overgrowth by seagrass epiphytes (Williams \& Heck 2001). From the 'top-down', the loss of top predators releases smaller predators that feed on grazers, thus reducing herbivore populations and decreasing their control of epiphytes. Strong 'top down' effects are most evident in freshwater systems with relatively simple trophic structures (Brooks \& Dodson 1965, Carpenter et al. 1987, Power 1990) but also occur in marine systems (Paine 1966, Estes \& Palmisano 1974, Wootton 1992). However, relatively few studies have simultaneously addressed both 'bottom-up' and 'top-down' influences in benthic marine communities (Wootton et al. 1996, Menge 2000, Worm et al. 2000), including seagrass beds (McGlathery 1995, Heck et al. 2000).

This study assessed the relative effects of 'bottomup' nutrient and 'top-down' consumer influences in regulating seagrass populations. Understanding the relative importance of nutrients and grazers may be necessary for reversing seagrass declines, given that the eutrophication and overfishing hypotheses predicate very different management responses. However, the relative importance of cascading effects from higher trophic levels in causing seagrass decline is difficult to assess because little experimental research has been done at more than 1 trophic level. Although the effects of epiphyte grazers have been studied fairly extensively (reviewed by Jernakoff et al. 1996), few studies have examined the factors, including predation, that control epiphyte grazer abundances (Main 1987, Edgar 1990, Schneider \& Mann 1991, Edgar \& Robertson 1992, Heck et al. 2000). In addition, few experimental manipulations of both nutrients and grazers have been conducted in seagrass beds (see Results). We conducted meta-analyses of experiments from 35 published seagrass studies in which nutrient concentrations and/or grazer abundances were manipulated to estimate the overall magnitude and relative importance of seagrass and epiphyte responses to nutrients and grazers. If grazers emerged as important drivers of seagrass responses, the inference would follow that higher-order trophic effects could be as well. 


\section{MATERIALS AND METHODS}

Study identification and selection. We conducted 2 extensive searches of the published literature. The first search targeted experiments testing grazer or nutrient effects on seagrasses. The second search involved publications containing data on effects of grazers or nutrients on seagrass epiphytes. Our searches uncovered very few manipulative experiments examining how nutrients or grazers influence macroalgal blooms associated with seagrass decline, which remains an important gap to fill. For both searches, we identified potential references using the Biosis and Web of Science electronic databases, which included literature published between 1985 and 2003. We searched both databases for the following keywords and their variants: nutrient, grazer, seagrass, epiphyte, herbivory, Zostera, Phyllospadix, Thalassia, Cymodocea, Halodule, Syringodium, and Posidonia; although the survey uncovered studies on additional species. We used the references cited in all studies identified through the searches to uncover additional sources, for a total of 140 citations. From these, we selected all identified laboratory and field experiments that met the following criteria: (1) grazers and/or nutrients were experimentally manipulated, (2) a seagrass or epiphyte response variable was measured, and (3) treatment and control sample sizes, means, and variance estimates were provided. The computer program TechDig V2.0 (Jones 1998, available at http:// home.xnet.com/ ronjones/\#TECHDIG) was used when necessary to extract data from figures.

The references that met our criteria were used to construct 2 final databases, one for seagrass response variables and one for epiphyte biomass. The final seagrass database included 28 suitable studies, which encompassed 420 cases (i.e. a comparison of a specific experimental treatment level against a control). We analyzed the effects of nutrients and grazers on 4 seagrass response variables: above-ground growth rate (20 studies, 78 cases); above-ground biomass (16 studies, 67 cases); below-ground biomass (10 studies, 42 cases); shoot density (12 studies, 62 cases). We analyzed data from the final sampling date of each experiment, regardless of total experimental duration. The epiphyte database included 15 suitable studies and a total of 43 cases, of which 8 studies and 17 cases were shared with the final seagrass database.

Decisions to include or exclude particular studies can have a large impact on the results of a meta-analysis, particularly if the number of studies is small (Englund et al. 1999, Gates 2002, Lajeunesse \& Forbes 2003). We used a single measure of each response variable for a given treatment to minimize non-independence among data points (Gurevitch et al. 1992, Englund et al. 1999, Gurevitch \& Hedges 1999). We created 2 additional data sets, one in which non-independent data were included, and one in which non-independent data and studies with low replication $(n=2)$ were excluded. In general, results were similar whether or not we restricted the data to a single measure of the response variable or eliminated studies with low replication; we present exceptions in the 'Results' section.

Meta-analysis. The program MetaWin 2.0 (Rosenberg et al. 2000) was used for all analyses. Effect sizes (i.e. differences between experimental and control means that are weighted by the standard deviation and sample size) and variances were calculated using the log-transformed response ratio (ln RR) metric, which provides a robust comparison of effect sizes (Gurevitch \& Hedges 2001). The results obtained from In RR were consistent with those from another effect size metric, Hedges' $d$ (data not presented; Gurevitch $\&$ Hedges 2001). To generate estimates of the degree and significance of variation within nutrient studies and grazer studies, we used a fixed-effects model, which assumes that all studies with similar characteristics have a single, true effect size in common (Gurevitch \& Hedges 1999, 2001). If there was significant variation in effect sizes within nutrients or grazers, we divided them into categories and assessed differences between these more specific comparisons: seagrass grazers versus epiphyte grazers, laboratory versus field studies, temperate versus tropical/subtropical seagrass species, individual seagrass species, water column versus sediment enrichment, and nutrient type. Epiphyte and seagrass grazers were designated according to information provided in the relevant study; when such information was not provided, we assigned categories based on the natural history of the organism. We then used a random-effects model to estimate mean effect sizes, confidence intervals and the probability of differences between categories. We generated confidence intervals with the conservative bias-corrected bootstrapping process (Hedges \& Olkin 1985, Gurevitch \& Hedges 2001). If the mean effect sizes of lab and field studies differed $(p<0.05)$ for grazers or nutrients (e.g. field nutrients versus lab nutrients), subsequent analyses within that group (e.g. nutrients) were run exclusively with field data to limit potentially confounding variation.

Effect sizes and variances were calculated for the epiphyte data set using the methods described above. An additional analysis of epiphyte responses was conducted by dividing studies of epiphyte biomass into 2 categories: (1) studies in which only epiphyte responses were measured (4 studies, 9 cases) and (2) studies in which both epiphyte and seagrass responses were measured (11 studies, 34 cases). The second group included studies that were excluded from our primary seagrass data- 
base for various reasons, including insufficient data reporting or the incompatibility of the measured seagrass response variable(s) with our analyses. We assessed the consistency of results between these categories by comparing the mean effect sizes of the 2 groups of grazer or nutrient manipulations. Similar responses would suggest that patterns from studies that only assess epiphyte responses could be used to infer impacts to seagrasses.
The duration of the experiments included in our seagrass analyses varied considerably (Table 1). To assess the effects of this variation on our results, we utilized data from experiments that measured seagrass above-ground growth rate at multiple times over the course of the experiment, which allowed us to standardize the data to a single common time interval (i.e. $90 \mathrm{~d}$ following the manipulation). We selected

Table 1. Classification information for references used as sources for meta-analysis data. AGB: above-ground biomass; AGR: above-ground growth rate; BGB: below-ground biomass; SD: shoot density; EB: epiphyte biomass; d: duration (d); n: no. cases/study; sed.: sediment enrichment; and water col.: water column enrichment. Genus abbreviations are C: Cymodocea; E: enhalus; H: Halodule (except Heterozostera tasmanica); P: Posidonia; R: Ruppia; S: Syringodium; T: Thalassia; and Z: Zostera

\begin{tabular}{|c|c|c|c|c|c|c|c|c|c|c|c|c|c|}
\hline \multirow[t]{2}{*}{ Region and species } & \multirow{2}{*}{$\begin{array}{c}\text { Study } \\
\text { description }\end{array}$} & \multicolumn{5}{|c|}{ Response(s) measured } & \multicolumn{5}{|c|}{ Nutrient treatment(s) d } & \multirow[t]{2}{*}{$\mathrm{n}$} & \multirow[t]{2}{*}{ Location and source } \\
\hline & & AGB & BGB & AGR & $\mathrm{SD}$ & EB & $\mathrm{N}$ & $\mathrm{P}$ & $\mathrm{N}, \mathrm{P}$ & $\mathrm{N}, \mathrm{P}, \mathrm{K}$ & & & \\
\hline \multicolumn{14}{|l|}{ Subtropical and Tropical } \\
\hline $\begin{array}{l}\text { C. rotundata, C. serrulata, } \\
\text { S. isoetifolium, T. hempr }\end{array}$ & $\begin{array}{l}\text { Field: sed. } \\
\text { ichii }\end{array}$ & & & $\mathrm{x}$ & $\mathrm{x}$ & & & & $\mathrm{x}$ & & $120-150$ & 44 & Indonesia (Erftemeijer et al. 1994) \\
\hline $\begin{array}{l}\text { C. rotundata, E. acoroides, } \\
\text { T. hemprichii }\end{array}$ & Field: sed. & $\mathrm{x}$ & & $\mathrm{x}$ & $\mathrm{x}$ & & & & & $\mathrm{x}$ & 120 & 14 & Philippines (Agawin et al. 1996) \\
\hline E. acoroides & Field: sed. & $\mathrm{x}$ & & $\mathrm{x}$ & & & & & $\mathrm{x}$ & & 98 & 24 & Philippines (Terrados et al. 1999) \\
\hline H. uninervis, $S$. isoetifolium & Field: sed. & $\mathrm{x}$ & $\mathrm{x}$ & $\mathrm{x}$ & $\mathrm{x}$ & & & & $\mathrm{x}$ & & 80 & 25 & Australia (Udy et al. 1999) \\
\hline H. wrightii & Lab: crustacean & $\mathrm{x}$ & $\mathrm{x}$ & $\mathrm{x}$ & $\mathrm{x}$ & $\mathrm{x}$ & & & & & 90 & 7 & USA (Howard \& Short 1986) \\
\hline H. wrightii, $R$. maritima & Field: sed. & & $\mathrm{x}$ & & & & & & & $\mathrm{x}$ & 35 & 8 & USA (Pulich 1985) \\
\hline H. wrightii, T. testudinum & Lab: water col. & & & & & $\mathrm{x}$ & $\mathrm{x}$ & $\mathrm{x}$ & $\mathrm{x}$ & & 28 & 6 & USA (Lapointe et al. 1994) \\
\hline S. filiforme & Field: sed. & & & $\mathrm{x}$ & & & $\mathrm{x}$ & $\mathrm{x}$ & $\mathrm{x}$ & & 210 & 7 & Bahamas (Short et al. 1990) \\
\hline S. filiforme, T. testudinum & Field: sed. & & & & $\mathrm{x}$ & & & & $\mathrm{x}$ & & 1110 & 2 & Virgin Islands (Williams 1990) \\
\hline T. testudinum & Field: turtle & & & $\mathrm{x}$ & $\mathrm{x}$ & & & & & & 90 & 2 & Virgin Islands (Williams 1988) \\
\hline T. testudinum & Field: urchin & $\mathrm{x}$ & & $\mathrm{x}$ & $\mathrm{x}$ & $\mathrm{x}$ & & & & & 120 & 8 & USA (Valentine et al. 1997) \\
\hline T. testudinum & Field: urchin & $\mathrm{x}$ & $\mathrm{x}$ & $\mathrm{x}$ & $\mathrm{x}$ & $\mathrm{x}$ & & & & & 90 & 18 & USA (Valentine et al. 2000) \\
\hline T. testudinum & $\begin{array}{l}\text { Field: water col., } \\
\text { fish }\end{array}$ & $\mathrm{x}$ & & $\mathrm{x}$ & $\mathrm{x}$ & $\mathrm{x}$ & $\mathrm{x}$ & & & & 176 & 11 & USA (Heck et al. 2000) \\
\hline T. testudinum & Lab: water col. & & & $\mathrm{x}$ & & $\mathrm{x}$ & & & $\mathrm{x}$ & & 30 & 2 & $\begin{array}{l}\text { USA, Mexico, Honduras } \\
\text { (Tomasko \& Lapointe 1991) }\end{array}$ \\
\hline T. testudinum & Field: sed. & $\mathrm{x}$ & $\mathrm{x}$ & & $\mathrm{x}$ & & $\mathrm{x}$ & & & & 180 & 7 & USA (Lee \& Dunton 2000) \\
\hline T. testudinum & Field: sed., urchin & $\mathrm{x}$ & & & & & & & $\mathrm{x}$ & & 70 & 6 & Bermuda (McGlathery 1995) \\
\hline T. testudinum & Field: urchin & $\mathrm{x}$ & & & & & & & & & 120 & 2 & USA (Heck \& Valentine 1995) \\
\hline T. testudinum & Field: urchin & $\mathrm{x}$ & $\mathrm{x}$ & & & & & & & & 42 & 8 & USA (Macia 2000) \\
\hline Z. japonica & Field: mollusc & & & & & $\mathrm{x}$ & & & & & 120 & 1 & China (Fong et al. 2000) \\
\hline \multicolumn{14}{|l|}{ Temperate } \\
\hline C. nodosa & Field: water col. & & & $\mathrm{x}$ & & & $\mathrm{x}$ & $\mathrm{x}$ & $\mathrm{x}$ & & 150 & 6 & Spain (Perez et al. 1991) \\
\hline H. tasmanica & Field: sed. & $\mathrm{x}$ & & & $\mathrm{x}$ & $\mathrm{x}$ & $\mathrm{x}$ & $\mathrm{x}$ & $\mathrm{x}$ & & 150 & 17 & Australia (Bulthuis et al. 1992) \\
\hline P. sinuosa & Field: crustacean & & & & & $\mathrm{x}$ & & & & & 35 & 3 & $\begin{array}{l}\text { Australia (Jernakoff \& } \\
\text { Nielsen 1997) }\end{array}$ \\
\hline Z. marina & $\begin{array}{l}\text { Field, Lab: water } \\
\text { col., crustacean }\end{array}$ & & & $\mathrm{x}$ & & $\mathrm{x}$ & $\mathrm{x}$ & & & & 20 & 10 & $\begin{array}{l}\text { USA (Williams \& } \\
\text { Ruckelshaus 1993) }\end{array}$ \\
\hline Z. marina & $\begin{array}{l}\text { Lab: mollusc, } \\
\text { crustacean }\end{array}$ & & & & & $\mathrm{x}$ & & & & & 14 & 3 & $\begin{array}{l}\text { Netherlands (Hootsmans \& } \\
\text { Vermaat 1985) }\end{array}$ \\
\hline Z. marina & Lab: water col. & $\mathrm{x}$ & $\mathrm{x}$ & & & $\mathrm{x}$ & $\mathrm{x}$ & $\mathrm{x}$ & $\mathrm{x}$ & & 180 & 11 & USA (Taylor et al. 1995) \\
\hline Z. marina & $\begin{array}{l}\text { Lab: water col., } \\
\text { mollusc, crustacean }\end{array}$ & & & & & $\mathrm{x}$ & & & $\mathrm{x}$ & & $30-60$ & 8 & USA (Neckles et al. 1993) \\
\hline Z. marina & Lab: mollusc & & & & & $\mathrm{x}$ & & & & & $10-12$ & 2 & USA (Nelson 1997) \\
\hline Z. marina & Lab: water col. & & & & & $\mathrm{x}$ & $\mathrm{x}$ & $\mathrm{x}$ & $\mathrm{x}$ & & 114 & 3 & USA (Lin et al. 1996) \\
\hline Z. marina & Field: sed. & & & $\mathrm{x}$ & & & & & $\mathrm{x}$ & & 243 & 6 & USA (Kenworthy \& Fonseca 1992) \\
\hline Z. marina & Field: sed. & & & $\mathrm{x}$ & & & $\mathrm{x}$ & $\mathrm{x}$ & $\mathrm{x}$ & & 49 & 6 & USA (Murray et al. 1992) \\
\hline Z. marina & Field: sed. & & & $\mathrm{x}$ & $\mathrm{x}$ & & & & & $\mathrm{x}$ & 210 & 8 & Germany (Worm \& Reusch 2000) \\
\hline Z. marina & Lab: crustacean & $\mathrm{x}$ & $\mathrm{x}$ & & & & & & & & 42 & 8 & USA (Duffy et al. 2001) \\
\hline Z. marina & Lab: sed., mollusc & $\mathrm{x}$ & $\mathrm{x}$ & $\mathrm{x}$ & & & $\mathrm{x}$ & $\mathrm{x}$ & $\mathrm{x}$ & & 45 & 4 & USA (Zimmerman et al. 1996) \\
\hline Z. marina & Lab: water col. & & & $\mathrm{x}$ & & & $\mathrm{x}$ & & & & 84 & 1 & USA (Burkholder et al. 1994) \\
\hline Z. marina & Lab: water col. & $\mathrm{x}$ & $\mathrm{x}$ & $\mathrm{x}$ & & & & & $\mathrm{x}$ & & 30 & 15 & USA (Moore \& Wetzel 2000) \\
\hline
\end{tabular}


studies on growth rate for this analysis because of the large range in experimental duration within this response variable (12 to $243 \mathrm{~d}$, see Table 1). Although there was larger variation in experimental duration for studies measuring shoot density, there were not enough time series data to run separate analyses. We analyzed the effects of grazers (4 studies, 7 cases) and nutrients (5 studies, 12 cases), as well as field sediment (3 studies, 10 cases) and water ( 2 studies, 2 cases) enrichments on aboveground growth rate for all instances in which a treatment and control were compared $90 \mathrm{~d}$ following the manipulation. If these results were consistent with the overall analyses, then the results were considered robust to variation in the duration of the experiments.

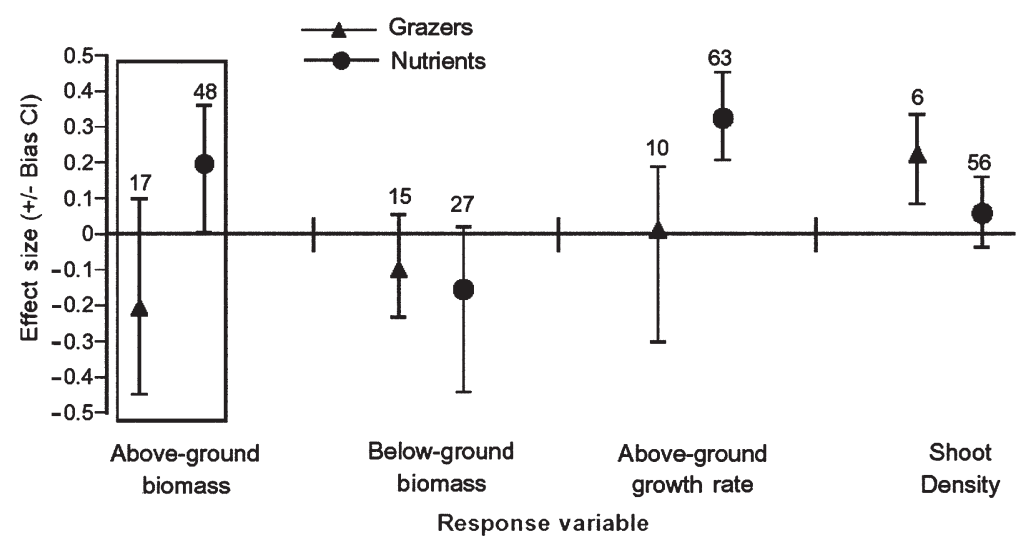

Fig. 2. Log-transformed response-ratio effect sizes (with bias confidence intervals) of grazer versus nutrient treatments for each of the 4 response variables. Effect sizes are significantly different from zero if confidence intervals do not overlap zero $(p<0.05)$. A box enclosing both values from 1 response variable indicates that those values were significantly different from each other $(p<0.05)$. Values at the upper edge of each bar indicate sample sizes for each effect size

\section{RESULTS}

Table 1 summarizes data from seagrass and epiphyte studies included in our analyses. Complete references are given in Appendix 1. Specific information for each of the cases is available on request.

In the results that follow, a significant effect is one for which the $95 \%$ bias confidence interval around the mean effect size does not include zero. Means indicate the effect size of a particular category (i.e. the difference between experimental and control groups). The p-values represent the probability that the difference(s) between the mean effect sizes of the categories being compared (e.g. laboratory nutrient studies versus field nutrient studies) are due to chance alone.

\section{All nutrients versus all grazers}

The overall effect of nutrient additions on aboveground biomass (mean $=0.20$ ) and above-ground growth rate $($ mean $=0.32$ ) was positive (Fig. 2 ). In contrast, the impact of nutrients on below-ground biomass and shoot density was negligible (Fig. 2). However, when we excluded 1 nutrient enrichment study (4 cases) with low replication, there was a significant positive effect of nutrient additions (mean $=0.14$ ) on below-ground biomass, consistent with the effects on above-ground biomass and growth rates.

All grazers combined had effects on above-ground biomass, below-ground biomass and above-ground growth rate that were not different from zero, but grazers resulted in an increase in shoot density (mean = 0.22) (Fig. 2).
Nutrients had a stronger overall effect than grazers on above-ground biomass $(p=0.04)$. However, the relative effects of grazers and nutrients on the remaining 3 response variables were not distinguishable. Further differentiation of the effects of nutrients and grazers required more refined comparisons using categories.

\section{Categorical comparisons for nutrients and grazers}

Water column versus sediment enrichment

Water column nutrient enrichment negatively affected above-ground biomass (mean $=-0.61$ ) and below-ground biomass (mean $=-0.55$ ), and these effects differed significantly $(p=0.001)$ from the positive impact of sediment nutrient additions on seagrass above- and below-ground biomass (means $=0.35,0.16$ ) (Fig. 3). The 2 methods of enrichment did not differentially affect growth rate. Low sample sizes prevented the comparison of shoot density responses to different enrichment methods.

Laboratory versus field nutrient manipulations

Whether nutrients were added in the laboratory or in mesocosms versus in the field led to strikingly different effects on above-ground biomass, below-ground biomass and above-ground growth rate ( $<$ <0.05) (Fig. 4). Laboratory nutrient additions caused no change in above-ground biomass or growth rate but a decline in 


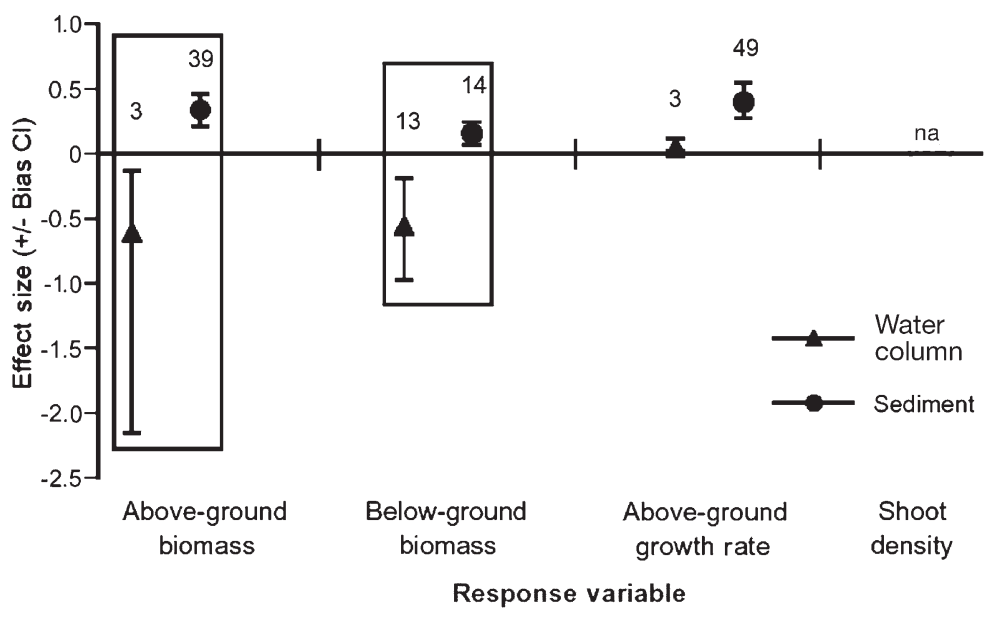

Fig. 3. Log-transformed response-ratio effect sizes (with bias confidence intervals) of enrichment type (water column versus sediment) for each of the 4 response variables. Effect sizes are different from zero if confidence intervals do not overlap zero $(\mathrm{p}<0.05)$. A box enclosing both values from 1 response variable indicates that those values were significantly different from each other $(\mathrm{p}<0.05)$. Values at the upper edge of each bar indicate sample sizes for each effect size. na indicates that not enough data were available for that analysis

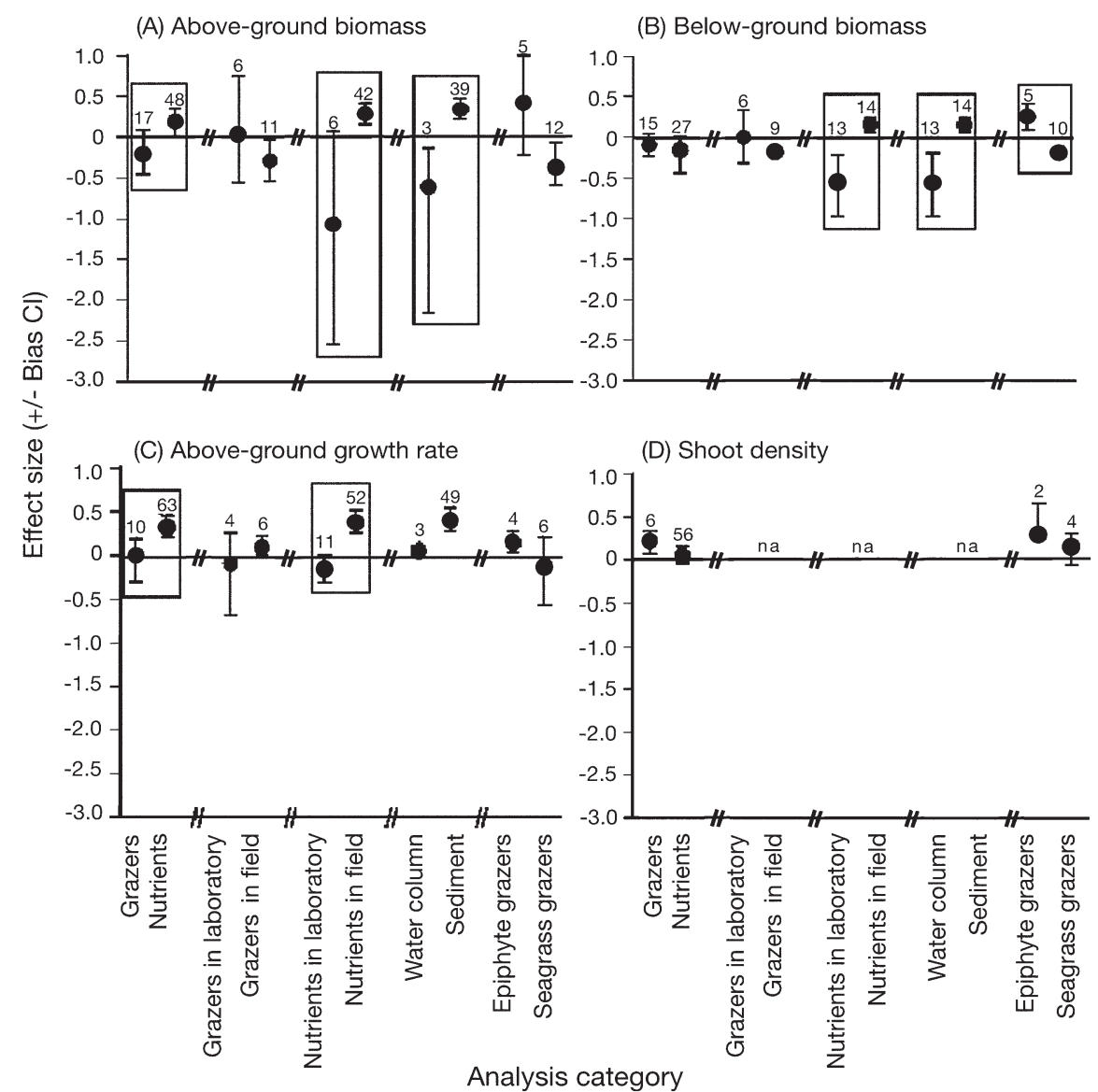

Fig. 4. Log-transformed response-ratio effect sizes (with bias confidence intervals) for each of the 4 seagrass response variables. Effect sizes are significantly different from zero if confidence intervals do not overlap zero ( $p<0.05)$. A box enclosing 2 values indicates that those values were significantly different from each other $(p<0.05)$. Values at the upper edge of each bar indicate sample sizes for each effect size. na indicates that not enough data were available for that analysis 
below-ground biomass (mean $=-0.55$ ), while nutrient enrichment in the field caused increases in these response variables (means $=0.29,0.38,0.16$, respectively). Shoot density responses to field and laboratory nutrient additions could not be compared due to insufficient laboratory manipulations. The water column was fertilized in most laboratory studies as opposed to the sediments in field manipulations (Table 1). When the difference in the site of enrichment is accounted for, the difference between responses to field and laboratory nutrient additions is consistent with results for water column versus sediment enrichment (see above). This pattern can be explained further by the results to follow on the response of epiphyte biomass to nutrient enrichments.

\section{Epiphyte versus seagrass grazers}

As expected, seagrass grazers had a negative effect on both above-ground biomass and below-ground biomass (mean $=-0.36$ and -0.19 , respectively) and tended to produce a negative effect on above-ground growth (Fig. 4). In direct contrast, the effects of epiphyte grazers on growth rate, below-ground biomass and shoot density were positive. Although epiphyte grazers had a positive effect on above-ground biomass (mean $=0.43$ ), the effect was highly variable among studies and thus, not different from zero. Despite the general differences between the negative effects of seagrass grazers and the positive impacts of epiphyte grazers, the 2 categories were only significantly different from each other for below-ground biomass $(p=0.001)$.

\section{Laboratory versus field grazer manipulations}

Negligible grazer effects on below-ground biomass in laboratory studies contrasted with the significantly negative impacts of grazers (mean $=-0.18$ ) on belowground biomass in field experiments ( $p=0.05$ ) (Fig 4). However, laboratory and field grazer manipulations resulted in indistinguishable responses in above-ground biomass and growth rate $(\mathrm{p}>0.05)$. Low sample sizes prevented the same comparison for shoot density.

\section{Other factors}

There were no differences between the effects of different nutrient combinations for any of the response variables $(\mathrm{p}>0.05)$, although the combination of nitro-

Table 2. Summary of mean effect sizes (log-transformed response-ratio) by seagrass species, nutrient type and geographic location for nutrient categories, and by seagrass species and geographic location for grazer categories. A numerical value is presented when the effect size differs significantly from zero $(p<0.05)$ and from other effect sizes within that category $(p<0.05)$; + or - : effect size differs significantly from zero $(p<0.05)$, but not from other effects within that category $(p>0.05) ; 0$ : effect size does not differ significantly from zero $(p>0.05)$. na: not enough data were available for that analysis

\begin{tabular}{|c|c|c|c|c|}
\hline & Above-ground biomass & Below-ground biomass & Above-ground growth rate & Shoot density \\
\hline \multicolumn{5}{|l|}{ Nutrient } \\
\hline \multicolumn{5}{|l|}{ Species comparison: } \\
\hline Halodule wrightii & 0.2513 & 0.1473 & na & 0.3700 \\
\hline Zostera marina & na & -0.5442 & 0.2235 & 0 \\
\hline Enhalus acaroides & 0.3201 & na & 0.3432 & na \\
\hline Thalassia hemprichii & 0.5978 & na & 0.2712 & 0 \\
\hline Thalassia testudinum & 0 & na & 0 & 0.2574 \\
\hline Halodule uninervis & 0.8094 & 0.1242 & 0 & na \\
\hline Ruppia maritima & 0.3041 & 0.2105 & na & na \\
\hline \multicolumn{5}{|l|}{ Nutrient type: } \\
\hline $\mathrm{N}$ & 0 & na & + & 0 \\
\hline $\mathrm{P}$ & 0 & na & 0 & + \\
\hline $\mathrm{N}$ and $\mathrm{P}$ & + & 0 & + & 0 \\
\hline $\mathrm{N}, \mathrm{P}$ and $\mathrm{K}$ & + & + & + & + \\
\hline \multicolumn{5}{|l|}{ Geographic comparison: } \\
\hline Tropical/subtropical & + & 0 & + & 0 \\
\hline Temperate & + & 0 & + & + \\
\hline \multicolumn{5}{|l|}{ Grazer } \\
\hline \multicolumn{5}{|l|}{ Species comparison: } \\
\hline Zostera marina & 0 & 0 & 0 & na \\
\hline Thalassia testudinum & - & - & 0 & na \\
\hline \multicolumn{5}{|l|}{ Geographic comparison: } \\
\hline Tropical/subtropical & 0 & - & + & 0 \\
\hline Temperate & 0 & 0 & 0 & + \\
\hline
\end{tabular}


gen, phosphorous, and potassium consistently resulted in a positive seagrass response (Table 2). With 2 exceptions, all seagrass species responded positively to nutrient additions, although to varying degrees (Table 2). The exceptions were that nutrients negatively impacted Zostera marina below-ground biomass (mean = -0.54) and Thalassia testudinum above-ground biomass (mean $=-0.09$ ). The effects of nutrients did not vary by geographic location ( $p>0.05)$ (Table 2$)$.

Grazer manipulations were primarily conducted with Zostera marina or Thalassia testudinum. Neither species responded to the presence of grazers overall ( $p>0.05$ ) (Table 2), a result that is not surprising given the opposing results between the categories of epiphyte versus seagrass grazers presented above. Low samples sizes prevented a comparison of epiphyte versus seagrass grazers for individual seagrass species. Grazer effects were consistent across tropical/subtropical and temperate locations for all response variables (p > 0.05) (Table 2).

\section{Epiphyte results}

Effect of nutrients on epiphyte biomass

Water column and sediment nutrient additions had strong contrasting effects on epiphyte biomass ( $\mathrm{p}=$ 0.04) (Fig. 5). Epiphyte biomass increased in response

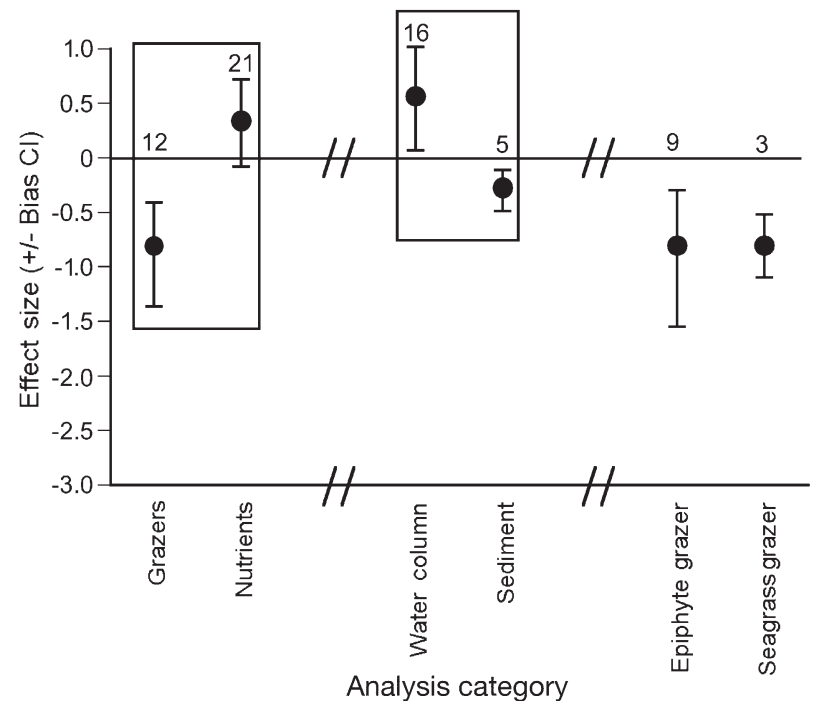

Fig 5. Log-transformed response-ratio effect sizes (with bias confidence intervals) of epiphyte biomass analyses. Effect sizes are significantly different from zero if confidence intervals do not overlap zero $(p<0.05)$. A box enclosing 2 values indicates that those values were significantly different from each other $(p<0.05)$. Values at the upper edge of each bar indicate sample sizes for each effect size to water column enrichment (mean $=0.56$ ) and decreased in response to sediment enrichment (mean $=-0.27$ ). The effect of nutrients on epiphyte biomass did not differ between studies measuring both epiphyte and seagrass responses and the single study (3 cases) that only evaluated the response of epiphytes ( $\mathrm{p}>0.05)$.

\section{Effect of grazers on epiphyte biomass}

Combined grazers had a strong negative effect on epiphyte biomass (mean $=-0.81$ ). Both seagrass grazer and epiphyte grazer categories individually suppressed epiphyte biomass. Curiously, the negative effect of grazers in studies assessing both epiphyte and seagrass response was different from the negligible impact of grazers found among studies measuring only epiphyte responses $(p=0.02)$. The small sample size of studies measuring only epiphyte responses to grazers ( $n=6$ cases) likely contributed to the large variation in effect sizes within this group, making the comparison less informative.

\section{Duration of the experiment}

When we controlled for variation in experimental duration (i.e. all data were taken $90 \mathrm{~d}$ following the manipulation), nutrient enrichments overall (mean = 0.42 ) and field sediment enrichments (mean $=0.50$ ) increased seagrass above-ground growth rate, consistent with results from the overall data set that varied in experimental duration from 12 to 243 d (see above, Fig. 2). There was a trend towards increased growth rate after $90 \mathrm{~d}$ due to water column nutrient additions, but this effect was not different from zero (in contrast to the small but significant effect of water enrichment in the overall analyses). Grazers had negligible effects on above-ground growth rate after $90 \mathrm{~d}$, also consistent with the overall data set.

\section{DISCUSSION}

The strength of a meta-analysis is that it can directly compare experiments that vary widely in execution. Although empirical studies have implicated both eutrophication and reduced epiphyte grazing pressure in seagrass declines, this study represents the first quantitative analysis of the relative effects of nutrients and grazers with respect to several factors including nutrient placement and identity, grazer type, experimental location and seagrass species. Our metaanalyses demonstrated that the negative effects of 
water column nutrients are comparable in magnitude to the positive effects of epiphyte grazers on seagrasses. In addition, our results confirmed that these effects are likely mediated through changes in epiphytes, as water column nutrients increased and epiphyte grazers decreased epiphyte biomass. Finally, the stark differences between lab and field nutrient manipulations, particularly in the site of nutrient enrichment, revealed the importance of experimental design and the use of caution when extrapolating results from the laboratory to the field.

Although seagrasses responded positively to many nutrient manipulations (including when all nutrient experiments were analyzed together), water column nutrient additions clearly had a negative impact on seagrass biomass. These results were consistent with predictions that epiphytes and/or macroalgae can outcompete seagrasses in the presence of excess water column nutrients. The subsequent analysis of the effect of nutrient manipulations on epiphytes revealed that water column nutrient additions increased epiphyte biomass, in sharp contrast to sediment nutrient additions. Sediment nutrient additions increased seagrass growth rates, resulting in less time for epiphyte accumulation (Borum 1987). Thus, our results supported the hypothesis that eutrophication contributes to seagrass decline by promoting epiphytic overgrowth.

The deleterious effects of macroalgal blooms on seagrass beds are gaining attention (McGlathery 2001), yet there were too few studies of macroalgae that directly manipulated nutrients or grazers to be included in our meta-analysis. Although large mats of drifting seaweeds have been observed in seagrass beds for over 20 yr (Williams Cowper 1977), they seem to be more apparent recently and have been linked to eutrophication (McGlathery 1995, Valiela et al. 1997). These observations have shifted the focus from epiphyte overgrowth to macroalgae as the cause for seagrass decline under eutrophication (Hauxwell et al. 2001). To bloom, macroalgae require higher loading rates than epiphytic algae because they maintain higher individual biomass and have longer turnover times and lower nutrient uptake rates (McGlathery 1992, Havens et al. 2001). Once nutrient loading rates are high enough to support macroalgal blooms, they persist a long time (Havens et al. 2001), which could lead to shading of epiphytes, as well as seagrasses (Hauxwell et al. 2003). We hypothesize that progressive increases in nutrient loading to coastal areas have led to a serial loss of seagrasses, first through overgrowth by epiphytes and then macroalgae. As studies on seagrass-macroalgal interactions accumulate, it will become possible to test this hypothesis, directly and through meta-analysis. Our analyses highlight the importance of considering both nutrient and consumer effects with respect to interactions between seagrass and macroalgae.

Positive seagrass responses to field and sediment nutrient enrichments indicated that nutrient limitation of seagrass growth and biomass is more common than anticipated by studies emphasizing light limitation (Dennison 1987, Zimmerman et al. 1987, Thom \& Albright 1990, Czerny \& Dunton 1995, Dunton 1996). Udy et al. (1999) suggested that increased nutrient loading from terrestrial sources has increased seagrass distribution and abundance on the Great Barrier Reef, rather than causing a decline. The relative importance of light versus nutrients in controlling seagrass decline merits a separate meta-analysis.

In addition to the strong 'bottom-up' effects of nutrient additions, we found support for the hypothesis that immediate 'top-down' forces can impact seagrasses. The lack of an impact of all grazers on seagrasses (Fig. 2) can be explained by the opposing effects of seagrass grazers and epiphyte grazers (Fig. 4). Our analyses support the contention of Valentine \& Heck (1999) that direct consumption of seagrasses has an important effect on seagrass growth rates and above- and below-ground biomass. Although they point out that seagrass herbivores can have a positive effect on seagrasses due to their capacity to compensate for loss of grazed tissues through utilization of carbohydrate reserves in below-ground rhizomes, our results provided evidence for an overall negative effect that was independent of the duration of the herbivory, particularly over the short-term before reserves would be depleted.

Epiphyte grazers also exhibited 'top-down' control through consistent, positive impacts on seagrass response variables (Fig. 4) and a strong negative effect on epiphyte biomass (Fig. 5). Many grazer studies, including a number of experiments in our analyses, have lumped grazers into functional groups based on similarity in body size and general diet. However, species-specific differences in the diets of small invertebrate grazers can underlie significant variation in epiphyte biomass and community composition, and have important implications for seagrass communities (Zimmerman et al. 1979, Kitting 1984, Duffy \& Hay 2000, Duffy \& Harvilicz 2001, Duffy et al. 2001). In particular, some key invertebrate grazers (e.g. Idotea resecata) consume both epiphytes and seagrasses, and thus, may have positive or negative effects depending on the context (Williams \& Ruckelshaus 1993). Furthermore, the species composition of algal epiphytes can shift under nutrient enrichment (Coleman \& Burkholder 1994, 1995), which could impact grazer diets. The divergent effects of seagrass and epiphyte grazers in our analyses emphasize the importance of understanding the diet of the particular grazer species manipulated. 
Despite our findings that epiphyte grazers benefit seagrasses by consuming epiphytes, our analyses cannot confirm the links between grazer abundances and higher trophic levels that form the basis of the overfishing hypothesis. A better understanding of factors controlling epiphyte grazer abundances is required. Until then, overgrowth of seagrasses by epiphytes following the loss of top predators can only be inferred. Theoretical and empirical research has demonstrated that complexities such as age-structured omnivory, intraguild predation and anti-consumer defenses can diminish the effects of strong 'top-down' forces or trophic cascades (Strong 1992, Polis \& Strong 1996, Duffy 2002). Small fishes (e.g. pinfish, Lagodon rhomboides) in seagrass systems consume both epiphytes and invertebrates during different parts of their life cycle (Heck et al. 2000), complicating predictions of the consequences of decreased predation pressure from large fish. Within the diverse seagrass-epiphyte association, organisms vary in trophic position and vulnerability to predators (Marsh 1973, Stoner 1980, Main 1987), making 'runaway consumption' less likely (Strong 1992). Epiphytes and seagrasses interact negatively within the same trophic level, which further complicates expectations for trophic cascades in seagrass food webs. Thus, the many direct and indirect links encompassed by the 'top-down' hypothesis increase the likelihood that higher-order trophic effects on seagrasses will be dampened.

Meta-analysis is a valuable tool for generalizing the results of experimental studies, but its power to generate insight into ecological processes is limited by the design of published studies, the quality of data reporting and the inherently coarse resolution of this type of analysis (Goldberg et al. 1999). We were forced to exclude nearly half of the experimental studies uncovered because variances were not supplied or graphs were scaled such that error bars overlapped and could not be differentiated. Although the duration of the experiments used in our analyses varied considerably, the effects of grazers and nutrients on seagrass growth rate at 90 d compared to a wide range of times did not differ, indicating that our results likely provided a robust indication of seagrass short-term response. We could not compare effects that might be evident over a longer term because we uncovered only a single study lasting longer than 1 yr. Certainly, persistent grazing pressure on seagrasses can lead to the depletion of stored reserves and contribute to seagrass decline (Camp et al. 1973, Williams 1988, Zimmerman et al. 1996).

In contrast to the consistency of results across different experimental durations, a striking difference emerged in our analyses between the effects of laboratory and field nutrient manipulations on seagrasses. We believe this difference was because the water col- umn was fertilized in the laboratory but the sediments in the field, favoring epiphytes versus seagrasses, respectively. We noted a tendency in the literature to generalize to nutrients overall, which is not necessarily appropriate considering the opposing effects of sediment versus water column enrichments. Few studies combined laboratory and field experiments (Williams \& Ruckelshaus 1993), a synthetic approach that would help to identify other factors contributing to the variation between the 2 settings.

Finally, simultaneous manipulations of grazers and nutrients were few, yet would allow an evaluation of the interactions between these factors. The need to include both factors in any assessment of the causal mechanisms behind seagrass declines is emphasized by studies showing that grazers can compensate for the effects of increased nutrients (Orth \& Van Montfrans 1984, Neckles et al. 1993, Williams \& Ruckelshaus 1993). An important caveat is that nutrient enrichment can also lead to at least transient catastrophic grazing of turtlegrass (Williams 1987, McGlathery 1995), in response to either increased epiphyte availability or more nutritious seagrass. Accordingly, rather than the last word on the relative importance of grazers and nutrients to seagrass communities, we view our analysis as a necessary first step in summarizing the available data and highlighting areas in need of further investigation.

For now, the consensus that epiphyte grazers have strong positive effects on seagrass biomass and growth was supported by our meta-analysis. A critical next step is to understand responses of epiphyte grazer populations to changes in higher trophic levels. The degree to which top predators have been lost in seagrass ecosystems is unclear, so their 'top-down' effect on epiphyte grazers remains conjectural. However, increases in water column nutrient concentrations have been documented in many coastal areas. In our analyses, such enrichment, associated with significant reductions in above-ground biomass and belowground biomass, had a strong overall effect on seagrasses. This result validates efforts to reduce nutrient loading to seagrass beds as an appropriate and necessary focus for management of these ecosystems.

Acknowledgements. This study was conducted as part of an Ecology 298 class, University of California-Davis. We thank E. Grosholz, M. Holyoak, J. Stachowicz, K. Heck and 2 anonymous reviewers for comments on the manuscript. This is contribution no. 2224 from Bodega Marine Laboratory.

\section{LITERATURE CITED}

Borum J (1987) Dynamics of epiphyton on eelgrass (Zostera marina L.) leaves: Relative roles of algal growth, 
herbivory, and substratum turnover. Limnol Oceanogr 32: 986-992

Brooks JL, Dodson SI (1965) Predation, body size and composition of plankton. Science 150:28-35

Camp DK, Cobb SP, Van Breedfield JV (1973) Overgrazing of seagrasses by a regular urchin, Lytechinus variegatus. BioScience 23:37-38

Carpenter SR, Kitchell JF, Hodgson JR, Cochran PA and 6 others (1987) Regulation of lake primary productivity by food web structure. Ecology 68:1863-1876

Cebrián J, Duarte CM (1998) Patterns in leaf herbivory on seagrasses. Aquat Bot 60:67-82

Coleman VL, Burkholder JM (1994) Community structure and productivity of epiphytic microalgae on eelgrass (Zostera marina L.) in experimental mesocosms under watercolumn nitrate enrichment. J Exp Mar Biol Ecol 179:29-48

Coleman VL, Burkholder JM (1995) Response of microalgal epiphyte communities to nitrate enrichment in an eelgrass (Zostera marina) meadow. J Phycol 31:36-43

Czerny AB, Dunton KH (1995) The effects of in situ light reduction on the growth of 2 subtropical seagrasses, Thalassia testudinum and Halodule wrightii. Estuaries 18: 418-427

Dayton PK, Tegner MJ, Edwards PB, Riser KL (1998) Sliding baselines, ghosts, and reduced expectations in kelp forest communities. Ecol Appl 8:309-322

Dennison WC (1987) Effects of light on seagrass photosynthesis, growth, and depth distribution. Aquat Bot 27:15-26

Duarte CM (1995) Submerged aquatic vegetation in relation to different nutrient regimes. Ophelia 41:87-112

Duffy JE (2002) Biodiversity and ecosystem function: the consumer connection. Oikos 99:201-219

Duffy JE, Harvilicz AM (2001) Species-specific impacts of grazing amphipods in an eelgrass-bed community. Mar Ecol Prog Ser 223:201-211

Duffy JE, Hay ME (2000) Strong impacts of grazing amphipods on the organization of a benthic community. Ecol Monogr 70:237-263

Duffy JE, MacDonald KS, Rhode JM, Parker JD (2001) Grazer diversity, functional redundancy, and productivity in seagrass beds: an experimental test. Ecology 82:2417-2434

Dunton KH (1996) Photosynthetic production and biomass of the subtropical seagrass Halodule wrightii along an estuarine gradient. Estuaries 19:436-447

Edgar GJ (1990) Population regulation, population dynamics, and competition amongst mobile epifauna associated with seagrass. J Exp Mar Biol Ecol 144:205-234

Edgar GJ, Robertson AI (1992) The influence of seagrass structure on the distribution and abundance of mobile epifauna: pattern and process in a Western Australian Amphibolis bed. J Exp Mar Biol Ecol 160:13-31

Englund G, Sarnelle O, Cooper SD (1999) The importance of data-selection criteria: meta-analyses of stream predation experiments. Ecology 80:1132-1141

Estes JA, Palmisano JF (1974) Sea otters: their role in structuring nearshore communities. Science 185:1058-1060

Fourqurean JW, Robblee MB (1999) Florida Bay: a history of recent ecological changes. Estuaries 22:345-357

Gates S (2002) Review of methodology of quantitative reviews using meta-analysis in ecology. J Anim Ecol 71:547-557

Goldberg DE, Rajaniemi T, Gurevitch J, Stewart-Oaten A (1999) Empirical approaches to quantifying interaction intensity: competition and facilitation along productivity gradients. Ecology 80:1118-1131

Gurevitch J, Hedges LV (1999) Statistical issues in ecological meta-analyses. Ecology 80:1142-1149

Gurevitch J, Hedges LV (2001) Meta-analysis: combining the results of independent experiments. In: Scheiner S, Gurevitch J (eds) The design and analysis of ecological experiments. Chapman \& Hall, New York, p 347-369

Gurevitch J, Morrow LL, Wallace A, Walsh JS (1992) A metaanalysis of competition in field experiments. Am Nat 140: $539-572$

Hall MO, Durako MJ, Fourqurean JW, Zieman JC (1999) Decadal changes in seagrass distribution and abundance in Florida Bay. Estuaries 22:445-459

Hauxwell J, McClelland J, Behr PJ, Valiela I (1998) Relative importance of grazing and nutrient controls of macroalgal biomass in 3 temperate shallow estuaries. Estuaries 21: $347-360$

Hauxwell J, Cebrián J, Furlong C, Valiela I (2001) Macroalgal canopies contribute to eelgrass (Zostera marina) decline in temperate estuarine ecosystems. Ecology 82:1007-1022

Hauxwell J, Cebrián J, Valiela I (2003) Eelgrass Zostera loss in temperate estuaries: relationship to land-derived nitrogen loads and effect of light limitation imposed by algae. Mar Ecol Prog Ser 247:59-73

Havens KE, Hauxwell J, Tyler AC, Thomas S and 5 others (2001) Complex interactions between autotrophs in shallow marine and freshwater ecosystems: implications for community responses to nutrient stress. Environ Pollut 113:95-107

Heck KL Jr, Pennock JR, Valentine JF, Coen LD, Sklenar SA (2000) Effects of nutrient enrichment and small predator density on seagrass ecosystems: an experimental assessment. Limnol Oceanogr 45:1041-1057

Hedges LV, Olkin I (1985) Statistical methods for metaanalysis. Academic Press, New York

Hootsmans MJM, Vermaat JE (1985) The effect of periphytongrazing by 3 epifaunal species on the growth of Zostera marina L. under experimental conditions. Aquat Bot 22:83-88

Howard RK (1982) Impact of feeding activities of epibenthic amphipods on surface-fouling of eelgrass leaves. Aquat Bot 14:91-97

Howarth RW, Anderson D, Cloern J, Elfring C and 7 others (2000) Nutrient pollution of coastal rivers, bays, and seas. Issues Ecol 7:1-15

Hughes TP, Baird AH, Bellwood DR, Card M and 13 others (2003) Climate change, human impacts, and the resilience of coral reefs. Science 301:929-933

Jackson JBC, Kirby MX, Berger WH, Bjorndal KA and 15 others (2001) Historical overfishing and the recent collapse of coastal ecosystems. Science 293:629-638

Jernakoff P, Brearley A, Nielsen J (1996) Factors affecting grazer-epiphyte interactions in temperate seagrass meadows. Oceanogr Mar Biol Annu Rev 34:109-162

Kitting CL (1984) Selectivity by dense populations of small invertebrates foraging among seagrass blade surfaces. Estuaries 7:276-288

Lajeunesse MJ, Forbes MR (2003) Variable reporting and quantitative reviews: a comparison of 3 meta-analytical techniques. Ecol Lett 6:448-454

Lenihan HS, Peterson CH (1998) How habitat degradation through fishery disturbance enhances impacts of hypoxia on oyster reefs. Ecol Appl 8:128-140

Main KL (1987) Predator avoidance in seagrass meadows: prey behavior, microhabitat selection and cryptic coloration. Ecology 68:170-180

Marsh GA (1973) The Zostera epifaunal community in the York River, Virginia. Chesapeake Sci 14:87-97

McGlathery KJ (1992) Physiological controls on the distribution of the macroalga Spyridea hypnoides: patterns along a eutrophication gradient in Bermuda. Mar Ecol Prog Ser 87:173-182 
McGlathery KJ (1995) Nutrient and grazing influences on a subtropical seagrass community. Mar Ecol Prog Ser 122: 239-252

McGlathery KJ (2001) Macroalgal blooms contribute to the decline of seagrass in nutrient-enriched coastal waters. J Phycol 37:453-456

Menge BA (2000) Top-down and bottom-up community regulation in marine rocky intertidal habitats. J Exp Mar Biol Ecol 250:257-289

Neckles HA, Wetzel RL, Orth RJ (1993) Relative effects of nutrient enrichment and grazing on epiphyte-macrophyte (Zostera marina L.) dynamics. Oecologia 93:285-295

Orth RJ, Moore KA (1983) Chesapeake Bay: an unprecedented decline in submerged aquatic vegetation. Science 222:51-53

Orth RJ, Van Montfrans J (1984) Epiphyte-seagrass relationships with an emphasis on the role of micrograzing: a review. Aquat Bot 18:43-69

Paine RT (1966) Food web complexity and species diversity. Am Nat 100:65-75

Polis GA, Strong DR (1996) Food web complexity and community dynamics. Am Nat 147:813-846

Power ME (1990) Effects of fish in river food webs. Science 250:811-814

Rosenberg MS, Adams DC, Gurevitch J (2000) MetaWin: statistical software for meta-analysis Version 2.0. Sinauer Associates, Sunderland, MA

Sand-Jensen K (1977) Effect of epiphytes on eelgrass photosynthesis. Aquat Bot 3:55-63

Sand-Jensen K, Revsbech NP, Jorgensen BB (1985) Microprofiles of oxygen in epiphyte communities on submerged macrophytes. Mar Biol 89:55-62

Schneider FI, Mann KH (1991) Species specific relationships of invertebrates to vegetation in a seagrass bed. II. Experiments on the importance of macrophyte shape, epiphyte cover and predation. J Exp Mar Biol Ecol 145:119-139

Short FT, Wyllie-Echeverria S (1996) Natural and humaninduced disturbance of seagrasses. Environ Conserv 23: $17-27$

Stankelis RM, Naylor MD, Boynton WR (2003) Submerged aquatic vegetation in the mesohaline region of the Patuxent Estuary: past, present, and future status. Estuaries 26: 186-195

Stoner AW (1980) Perception and choice of substratum by epifaunal amphipods associated with seagrasses. Mar Ecol Prog Ser 3:105-111

Strong DR (1992) Are trophic cascades all wet? Differentiation and donor-control in speciose ecosystems. Ecology 73: 747-754

Thayer GW, Bjorndal KA, Ogden JC, Williams SL, Zieman JC (1982) Role of large herbivores in seagrass communities. Estuaries 7:351-376

Thom RM, Albright RG (1990) Dynamics of benthic vegetation standing-stock, irradiance, and water properties in central Puget Sound. Mar Biol 104:129-141

Udy JW, Dennison WC, Long WJL, Mckenzie LJ (1999) Responses of seagrass to nutrients in the Great Barrier Reef, Australia. Mar Ecol Prog Ser 185:257-271

Valentine JF, Heck KL Jr (1991) The role of sea urchin grazing in regulating subtropical seagrass meadows: evidence from field manipulations in the northern Gulf of Mexico. J Exp Mar Biol Ecol 154:215-230

Valentine JF, Heck KL Jr (1999) Seagrass herbivory: evidence for the continued grazing of marine grasses. Mar Ecol Prog Ser 176:291-302

Valiela I, McClelland J, Hauxwell J, Behr PJ, Hersh D, Foreman K (1997) Macroalgal blooms in shallow estuaries: controls and ecophysiological and ecosystem consequences. Limnol Oceanogr 42:1105-1118

Walker DI, McComb AJ (1992) Seagrass degradation in Australian coastal waters. Mar Pollut Bull 25:191-195

Williams SL (1987) Competition between the seagrasses Thalassia testudinum and Syringodium filiforme in a Caribbean lagoon. Mar Ecol Prog Ser 35:91-98

Williams SL (1988) Thalassia testudinum productivity and grazing by green turtles in a highly disturbed seagrass bed. Mar Biol 98:447-455

Williams SL, Heck KL Jr (2001) Seagrass communities. In: Bertness MD, Gaines S, Hay ME (eds) Marine community ecology. Sinauer Press, Sunderland, MA, p 317-337

Williams SL, Ruckelshaus MH (1993) Effects of nitrogen availability and herbivory on eelgrass (Zostera marina) and epiphytes. Ecology 74:904-918

Williams Cowper S (1977) The drift algae community of seagrass beds in Redfish Bay, Texas. Cont Mar Sci 21: $125-132$

Wootton JT (1992) Indirect effects, prey susceptibility, and habitat selection: impacts of birds on limpets and algae. Ecology 73:981-991

Wootton JT, Power ME, Paine RT, Pfister CA (1996) Effects of productivity, consumers, competitors, and El Niño events on food chain patterns in a rocky intertidal community. Proc Natl Acad Sci USA 93:13855-13858

Worm B, Lotze HK, Sommer U (2000) Coastal food web struture, carbon storage, and nitrogen retention regulated by consumer pressure and nutrient loading. Limnol Oceanogr 45:339-349

Zimmerman R, Gibson RA, Harrington J (1979) Herbivory and detritivory among gammaridean amphipods from a Florida seagrass community. Mar Biol 54:41-47

Zimmerman RC, Smith RD, Alberte RS (1987) Is growth of eelgrass nitrogen limited? A numerical simulation of the effects of light and nitrogen on the growth dynamics of Zostera marina. Mar Ecol Prog Ser 41:167-176

Zimmerman RC, Kohrs DG, Alberte RS (1996) Top-down impact through a bottom-up mechanism: the effect of limpet grazing on growth, productivity, and carbon allocation of Zostera marina L. (eelgrass). Oecologia 107:560-567 
Appendix 1. Sources of data for meta-analyses

Agawin NSR, Duarte CM, Fortes MD (1996) Nutrient limitation of Philippine seagrasses (Cape Bolinao, NW Philippines): in situ experimental evidence. Mar Ecol Prog Ser 138:233-243

Bulthuis DA, Axelrad DM, Mickelson MJ (1992) Growth of the seagrass Heterozostera tasmanica limited by nitrogen in Port Phillip Bay, Australia. Mar Ecol Prog Ser 89: 269-275

Burkholder JM, Glasgow HB, Cooke JE (1994) Comparative effects of water-column nitrate enrichment on eelgrass Zostera marina, shoalgrass Halodule wrightii, and widgeongrass Ruppia maritima. Mar Ecol Prog Ser 105: 121-138

Duffy JE, MacDonald KS, Rhode JM, Parker JD (2001) Grazer diversity, functional redundancy, and productivity in seagrass beds: an experimental test. Ecology 82: $2417-2434$

Erftemeijer PLA, Stapel J, Smekens MJE, Drossaert WME (1994) The limited effect of in situ phosphorus and nitrogen additions to seagrass beds on carbonate and terrigenous sediments in South Sulawesi, Indonesia. J Exp Mar Biol Ecol 182:123-140

Fong CW, Lee SY, Wu RSS (2000) The effects of epiphytic algae and their grazers on the intertidal seagrass Zostera japonica. Aquat Bot 67:251-261

Heck KL Jr, Valentine JF (1995) Sea urchin herbivory: evidence for long-lasting effects in subtropical seagrass meadows. J Exp Mar Biol Ecol 189:205-217

Heck KL Jr, Pennock JR, Valentine JF, Coen LD, Sklenar SA (2000) Effects of nutrient enrichment and small predator density on seagrass ecosystems: an experimental assessment. Limnol Oceanogr 45:1041-1057

Hootsmans MJM, Vermaat JE (1985) The effect of periphyton grazing by three epifaunal species on the growth of Zostera marina under experimental conditions. Aquat Bot 22:83-88

Howard RK, Short FT (1986) Seagrass (Halodule wrightii) growth and survivorship under the influence of epiphyte grazers. Aquat Bot 24:287-302

Jernakoff P, Nielsen J (1997) The relative importance of amphipod and gastropod grazers in Posidonia sinuosa meadows. Aquat Bot 56:183-202

Kenworthy WJ, Fonseca MS (1992) The use of fertilizer to enhance growth of transplanted seagrasses Zostera marina L. and Halodule wrightii Aschers. J Exp Mar Biol Ecol 163:141-161

Lapointe BE, Tomasko DA, Matzie WR (1994) Eutrophication and trophic state classification of seagrass communities in the Florida Keys. Bull Mar Sci 54:696-717

Lee KS, Dunton KH (2000) Effects of nitrogen enrichment on biomass allocation, growth, and leaf morphology of the seagrass Thalassia testudinum. Mar Ecol Prog Ser 196: $39-48$

Lin HJ, Nixon SW, Taylor DI, Granger SL, Buckley BA (1996) Responses of epiphytes on eelgrass, Zostera marina L., to separate and combined nitrogen and phosphorus enrichments. Aquat Bot 52:243-258

Macia S (2000) The effects of sea urchin grazing and drift algal blooms on a subtropical seagrass bed community. J Exp Mar Biol Ecol 246:53-67

McGlathery KJ (1995) Nutrient and grazing influences on a subtropical seagrass community. Mar Ecol Prog Ser 122:239-252
Moore KA, Wetzel RL (2000) Seasonal variations in eelgrass (Zostera marina L.) responses to nutrient enrichment and reduced light availability in experimental ecosystems. J Exp Mar Biol Ecol 244:1-28

Murray L, Dennison WC, Kemp WM (1992) Nitrogen versus phosphorus limitation for growth of an estuarine population of eelgrass (Zostera marina L). Aquat Bot 44:83-100

Neckles HA, Wetzel RL, Orth RJ (1993) Relative effects of nutrient enrichment and grazing on epiphytemacrophyte (Zostera marina L.) dynamics. Oecologia 93:285-295

Nelson TA (1997) Epiphyte-grazer interactions on Zostera marina (Anthophyta: Monocotyledones): effects of density on community function. J Phycol 33:743-752

Perez M, Romero J, Duarte CM, Sand-Jensen K (1991) Phosphorus limitation of Cymodocea nodosa growth. Mar Biol 109:129-133

Pulich WMJ (1985) Seasonal growth dynamics of Ruppia maritima and Halodule wrightii in southern Texas USA and evaluation of sediment fertility status. Aquat Bot 23:53-66

Short FT, Dennison WC, Capone DG (1990) Phosphorus-limited growth of the tropical seagrass Syringodium filiforme in carbonate sediments. Mar Ecol Prog Ser 62:169-174

Taylor DI, Nixon SW, Granger SL, Buckley BA, McMahon JP, Lin HJ (1995) Responses of coastal lagoon plant communities to different forms of nutrient enrichment: a mesocosm experiment. Aquat Bot 52:19-34

Terrados J, Agawin NSR, Duarte CM, Fortes MD, KampNielsen L, Borum J (1999) Nutrient limitation of the tropical seagrass Enhalus acoroides (L.) Royle in Cape Bolinao, NW Philippines. Aquat Bot 65:123-139

Tomasko DA, Lapointe BE (1991) Productivity and biomass of Thalassia testudinum as related to water column nutrient availability and epiphyte levels: field observations and experimental studies. Mar Ecol Prog Ser 75:9-17

Udy JW, Dennison WC, Lee Long WJ, McKenzie LJ (1999) Responses of seagrass to nutrients in the Great Barrier Reef, Australia. Mar Ecol Prog Ser 185:257-271

Valentine JF, Heck KL Jr, Busby J, Webb D (1997) Experimental evidence that herbivory increases shoot density and productivity in a subtropical turtlegrass (Thalassia testudinum) meadow. Oecologia 112:193-200

Valentine JF, Heck KL Jr, Kirsch KD, Webb D (2000) Role of sea urchin Lytechinus variegatus grazing in regulating subtropical turtlegrass Thalassia testudinum meadows in the Florida Keys (USA). Mar Ecol Prog Ser 200:213-228

Williams SL (1988) Thalassia testudinum productivity and grazing by green turtles in a highly disturbed seagrass bed. Mar Biol 98:447-456

Williams SL (1990) Experimental studies of Caribbean seagrass bed development. Ecol Monogr 60:449-469

Williams SL, Ruckelshaus MH (1993) Effects of nitrogen availability and herbivory on eelgrass (Zostera marina) and epiphytes. Ecology 74:904-918

Worm B, Reusch TBH (2000) Do nutrient availability and plant density limit seagrass colonization in the Baltic Sea? Mar Ecol Prog Ser 200:159-166

Zimmerman RC, Kohrs DG, Alberte RS (1996) Top-down impact through a bottom-up mechanism: the effect of limpet grazing on growth, productivity and carbon allocation of Zostera marina L. (eelgrass). Oecologia 107: 560-567 